\title{
Overview of Contemporary Issues of Forest Research and Management in China
}

\author{
Hong S. He • Stephen R. Shifley • \\ Frank R. Thompson III
}

Received: 31 August 2011/Accepted: 24 October 2011/Published online: 11 November 2011

(C) Springer Science+Business Media, LLC 2011

\begin{abstract}
With 207 million ha of forest covering 22\% of its land area, China ranks fifth in the world in forest area. Rapid economic growth, climate change, and forest disturbances pose new, complex challenges for forest research and management. Progress in meeting these challenges is relevant beyond China, because China's forests represent $34 \%$ of Asia's forests and 5\% of the worlds' forests. To provide a broader understanding of these management challenges and of research and policies that address them, we organized this special issue on contemporary forest research and management issues in China. At the national level, papers review major forest types and the evolution of sustainable forestry, the development of China's forestcertification efforts, the establishment of a forest inventory system, and achievements and challenges in insect pest control in China. Papers focused on Northern China address historical, social, and political factors that have shaped the region's forests; the use of forest landscape models to assess how forest management can achieve multiple objectives; and analysis and modeling of fuels and fire behavior. Papers addressing Central and South China describe the "Grain for Green" program, which converts low productivity cropland to grassland and woodland to
\end{abstract}

H. S. He

State Key Laboratory of Forest and Soil Ecology, Institute of Applied Ecology, Chinese Academy of Sciences,

Shenyang 110016, China

H. S. He $(\square)$

School of Natural Resources, University of Missouri, Columbia, MO 65211, USA

e-mail: heh@missouri.edu

S. R. Shifley · F. R. Thompson III

USDA Forest Service, Northern Research Station, Columbia, MO 65211, USA address erosion and soil carbon sequestration; the potential effects of climate change on $\mathrm{CO}_{2}$ efflux and soil respiration; and relationships between climate and net primary productivity. China shares many forest management and research issues with other countries, but in other cases China's capacity to respond to forest management challenges is unique and bears watching by the rest of the world.

Keywords Forest ecosystem service $\cdot$ Forest certification . Forest pest management $\cdot$ Forest inventory database $\cdot$ Forest management history $\cdot$ Forest fire modeling

\section{Introduction}

China is one of the largest countries in the world; it has a 960 million $\mathrm{km}^{2}$ land area and a population of 1.3 billion. From north to south, China spans five climatic zones that include boreal coniferous forests, temperate mixed coniferous and broadleaf forests, temperate broadleaf forests, subtropical evergreen broadleaf forests, and tropical forests. These forests are home to over 8,000 vascular plant species, including 2,000 tree species. China has 207 million ha of forest, which cover $22 \%$ of its land area. China ranks fifth in the world in forest area following the Russian Federation, Brazil, Canada, and the United States of America (FAO 2010). However, China's forest cover is below the world average of $31 \%$, and China has 0.15 ha of forest per capita, which is much less than the world average of 0.6 ha. The total carbon stock in the living forest biomass is 6.2 billion metric tons.

From 1990 to 2010, China's forests experienced significant changes through aggressive afforestation. China has a larger proportion of planted forests-approximately 
$37 \%$ of its forest area-than most other nations. In Asia and the Pacific region as a whole, forests were lost at a rate of 0.7 million ha per year in the 1990s but grew by 1.4 million ha per year over the period 2000-2010. This was primarily because of large-scale afforestation efforts in China, where the forest area increased by 2 million ha per year in the 1990s and by an average 3 million ha per year since 2000. China has established targets for large-scale forest planting and also developed incentive programs for individual forest landowners to plant more trees. China plans a 50 million ha increase in the area of its planted forests by 2020 (Central Committee of the Communist Party of China and China State Council 2010), with the aim of covering $23 \%$ of the total land area with forests, a target which may be reached by 2015 if current planting rates continue. Because the planted forests are relatively young, they have lower average volume and less sequestered carbon than China's natural forests (SFA 2009).

For the past three decades, China has enjoyed an average of $9.9 \%$ annual GDP growth, the fastest growing economy in the world. China's growing industrial output and the improving domestic standard of living exert tremendous pressure on natural resources in China. Climate change along with such disturbances as wildfires, insects and disease, extensive forest harvesting, and expansion of urban areas pose new, complex challenges for forest research and management (Zhang and others 2000). Progress in meeting these challenges is relevant beyond China, because China's forests represent $34 \%$ of Asia's forests and $5 \%$ of the worlds' forests.

To provide a broader understanding of these management challenges and of research and policies that address them, we compiled this special issue on contemporary forest research and management issues in China. This special issue is organized in three sections (1) forest research and management issues at the national level, (2) applications in Northern China, and (3) applications in Central and Southern China.

\section{Forest Research and Management at the National Level}

The paper, Major forest types and the evolution of sustainable forestry in China, by Dai and others (this issue) characterizes China's forests and discusses the history of forest management in China. Excessive exploitation of China's forest resources from the 1950s to the late 1990s contributed to major environmental problems, such as floods, soil erosion, and desertification. At the start of the new millennium, the Chinese government shifted its emphasis from timber production toward sustainable forest management (SFM). With the adoption of a classification system for China's forests, the implementation of several key national forest projects, and the reform of forest tenure policies, the country began to reverse the trend of environmental degradation that occurred throughout the latter half of the twentieth century.

Forests in China provide multiple ecosystem services and their importance is frequently underestimated. To overcome this issue, China recently established the forest eco-compensation program with the goal of internalizing the externalities of forest ecosystem services by compensating individuals or companies for the losses or costs of providing these services. Deng and others (this issue) discusses forest eco-compensation mechanisms and systems in China, which recognize the ecological benefits of forests and try to fundamentally solve the incentive and delivery mechanism problems. They argue that it is crucial to design and establish compensation criteria for non-commercial forests with both theoretical and practical concerns taken into account and that are based on the quantitative valuation of ecosystem services.

Forest certification is a mechanism to establish incentives for forest owners and forest businesses to conform to environmentally and socially responsible forest practices. It sets standards for forest management and for timber harvesting, processing, distribution, and trade. Certification has been widely adopted in North America and Europe (Forest Stewardship Council 2011; Sustainable Forest Initiative 2011). China has great potential to reap ecological and economic benefit from implementing forest-certification programs, but doing so is a massive undertaking. Currently $10,000 \mathrm{~km}^{2}$ of China's forest land is certified, but that is less than $1 \%$ of the total forest area. Zhao and others (this issue) discuss three important factors that have constrained the development of China's forest-certification efforts: (1) institutional factors including centralized forest plans with limited flexibility; (2) limited public awareness of certification which limits consumer demand for certified forest products; and (3) the high initial cost of certification. Nevertheless, Zhao and others (this issue) estimate that, in the long run, the added value to forest products resulting from forest certification in China would greatly exceed the costs of certification.

The condition of China's forest resources is monitored through a three-tiered forest inventory system that since 1973 has provided information designed to meet needs at national, provincial, and local (operational) spatial scales (Xie and others this issue). The National Forest Continuous Inventory (NFCI) is the first tier of this system and is a systematic inventory of all forests on a 5-year cycle with mathematical modeling used to update forest characteristics for years between field inventories. Information derived from this database is important for the formulation and refinement of national forest policy, planning, and management. The Forest Management Planning Inventory 
(FMPI) - the second tier of China's inventory system-is repeated every 10 years for all lands administered by state forestry bureaus in Chinese provinces, as well as for natural reserves and county administrative units. FMPI data are the basis for forest-planning and harvesting-quota decisions. The third tier, the Forest Operation Design Inventory (FODI), is an intensive inventory of the individual management units (subcompartments) and is used to prescribe and implement management activities on the ground. Recent technological advances have increased access to and utility of forest inventory information though webbased data access and utilization of three-dimensional spatial visualization to display current and expected future forest conditions.

There are more than 8,000 species of forest pests, including insects, plant diseases, rodents and lagomorphs, and hazardous plants in China. Among them, 300 species are considered as economically or ecologically important, and half of these are serious pests, including 86 species of insects. Ji and others (this issue) present a comprehensive overview of achievements and challenges in insect pest control in China. They summarize the current status of forest resources and forest pests in China. They discuss the theories, policies, practices and major national initiatives of insect pest management. They analyze three representative plantations-eucalyptus, poplar and Masson pine plantations - with respect to their insect diversity, pest problems, and pest management measures as references for China's pest management.

\section{Forest Research and Management in Northern China}

Northeast China has the largest relatively contiguous forest areas in China. The region includes coniferous boreal forests in the north and mixed coniferous and broadleaf temperate forests in the south. Forests in the Northeast were explored and exploited much later than those in eastern and southern parts of the country. Yu and others (this issue) briefly describe the historical, social, and political factors-including repeated foreign invasionsthat have shaped the current conditions of the region's forests. Periods of excessive logging and neglected cultivation resulted in substantial decreases in the area of natural forests and serious degradation of forest quality prior to 1980. Subsequent reforms have resulted in increased emphasis on multiple-use, sustainable forest management and on maintaining biodiversity. Implementation of the National Forest Conservation Program in 1998 has substantially reduced harvest levels, and a Classification-based Forest Management (CFM) system distinguishes forest lands managed for commodity production from those managed primarily for ecosystem services. This latter category, termed Ecological Welfare Forest, now encompasses nearly $40 \%$ of the forest land in Northeast China. Development and implementation of suitable multiple-use management methods for all categories of forest are complicated by the enduring effects of past events that have diminished the extent and diversity of the region's forests.

Balancing multiple management objectives under CFM is challenging because of the intrinsic conflicts among multiple-use forest management objectives and a lack of reference conditions for evaluating the effectiveness of forest restoration efforts. Zhao and others (this issue) used a spatially explicit forest landscape model (LANDIS) to assess how well the CFM system can achieve multiple objectives in a Korean pine, broadleaf, mixed forest ecosystem in Northeast China. They evaluated a natural disturbance scenario, the current harvest scenario, and six other scenarios to model how tree species' composition, age structure, and timber production at the landscape level can be affected by alternative management strategies under the CFM system. The results indicated that the current forest management regime would not only fail to reach the designated timber production level but also move the forest landscape further away from its range of natural variability (RNV). In order to move the current (highly altered) forest landscape toward its RNV while providing stable timber production over time, it appears that harvest intensities for native forest should be reduced to a level that is roughly equivalent to the amount of timber mortality that would occur under the natural disturbances while establishing additional plantations though afforestation.

Fire is an important disturbance process in many forest ecosystems in China. Fire effects on forest ecosystems are experienced though wildfire and prescribed burning as well as through fire suppression and exclusion. Application of contemporary statistical models to assess wildfire risk, to model fire spread, and to develop plans for prescribed burning requires knowledge of forest fuels and the expected fire behavior when the fuels are ignited. Following five decades with an overriding emphasis on fire suppression, new research in Northeast China is focused on methods to inventory and model forest fuel and fire behavior for a wide range of forest conditions. $\mathrm{Wu}$ and others (this issue) present four customized fire behavior models that differ significantly in fuel characteristics and environmental conditions. They applied hierarchical cluster analysis to fuels data collected across a boreal forest landscape in Northeastern China to quantify differences in fuel characteristics associated with differences in forest vegetation and site conditions. Their analyses identified four distinct fuel models that can be applied with the BehavePlus5.0 firebehavior prediction system developed in United States and Canada. The simulated fire behavior produced by each fuel model is now being validated. 


\section{Forest Research and Management in Central and Southern China}

To mitigate the climate-warming effects, attention has been paid to increasing soil organic carbon (SOC), since SOC storage is about two and three times the size of carbon pools in the atmosphere and vegetation, respectively. The next three studies focus on soil carbon sequestration in Central and Southern China. Conversion of cropland into perennial vegetation land can increase SOC, which may mitigate the effects of increasing atmospheric carbon dioxide because of fossils fuel burning. Chang and others (this issue) describe The "Grain for Green" project, one of the most ambitious ecological programs launched in Central China. The project aimed at transforming the low-yield slope cropland into grassland and woodland. The Loess Plateau in China is the most important target of this project because of its serious soil erosion. Converting the lowyield cropland into permanent grassland and shrub land curbed soil erosion and increased SOC. They found that the "Grain for Green" project can significantly increase the SOC storage on the Loess Plateau, and they recommend expansion of grassland and shrub areas in the northern Loess Plateau and forest in the middle and southern Loess Plateau to enhance the SOC sequestration in this area.

Soil $\mathrm{CO}_{2}$ efflux is the largest terrestrial source of $\mathrm{CO}_{2}$ contributing to atmospheric $\mathrm{CO}_{2}$, and is about $68-80 \mathrm{Pg} \mathrm{C}$ year ${ }^{-1}$ on a global scale. Even small change in soil $\mathrm{CO}_{2}$ efflux could significantly exacerbate or mitigate the buildup of the greenhouse gas in the atmosphere, which in turn could further alter climate. Climate models and satellite observations have predicted fewer but larger precipitation events in southern China. Understanding the effects of such a climate change on soil $\mathrm{CO}_{2}$ efflux is important for managing subtropical forests in Southern China. Deng and others (this issue) designed experimental studies of precipitation pulses of varying intensities using precipitation simulations of two subtropical forests. They found that soil $\mathrm{CO}_{2}$ efflux could be changed via pulse-like fluxes in subtropical forests in Southern China as fewer but more extreme precipitation events occur in the future. Considering that subtropical forests will receive fewer, but larger precipitation events in the near future, these findings may have potentially significant implications for terrestrial ecosystem carbon cycling.

Huang and others (this issue) studied soil respiration rate and long-term soil microclimate change in Southern China. They analyzed temporal trends and variation in air temperature, soil temperature, and soil water content and then estimated soil respiration rates in the 1980s and 2000s with soil temperature and soil water content in three subtropical forests in early-, mid-, and late-successional stages. They found that changes of soil temperature and soil water content caused by climatic change may produce a negative effect on soil respiration rates for all three forests. They assert soil respiration may have a negative feedback on regional climate change and that less carbon could be sequestered in subtropical forests in Southern China.

Terrestrial net primary production (NPP) is the main source for human food resources, wood products, and fuel. Understanding the effects of climate factors on NPP is important especially under climate warming. $\mathrm{Li}$ and others (this issue) used NPP data for 221 forest sites and their related environmental variables for Eastern China from the Ecosystem Model-Data Intercomparison (EMDI) project, to quantify the response patterns of forest NPP in Eastern China to seasonal climate variables. They found that winter temperature and sunshine duration negatively affected NPP, while winter precipitation positively affected NPP, and spring temperature had a positive effect on NPP, which was likely because a favorable warm climate in the early growing season promotes forest growth. Forest NPP was also negatively affected by summer and autumn temperatures, possibly because these are related to temperatureinduced drought stress. This study provides insight into the seasonal effects of climate and NPP of forests in China as well as useful knowledge for the development of climatevegetation models.

\section{Concluding Thoughts}

Readers of this special issue will see that forest management challenges in China are similar to those facing other nations. For example, in China as elsewhere there is a need for effective multi-scale inventory systems; application of science-based forest-classification and management methods; efficient inventory systems; development of improved forecasting tools; and application of multiple-objective forest management plans at national, regional, and local scales. In other cases, however, China's capacity to respond to forest management challenges is unique and bears watching by the rest of the world. For example, the recent, massive afforestation and artificial regeneration efforts in China are unmatched, and the outcomes of those efforts will be of interest elsewhere. Likewise China's centralized approach to forest management differs from the decentralized management approaches used by many other heavily forested nations. Consequently, there will continue to be interest in China's effectiveness in addressing the complex challenges of sustainable forest management.

Acknowledgments We thank all contributors who helped organizing this special issue. We thank Virginia Dale for the support of publishing this special issue. We also thank anonymous reviewer who improved the clarity of this paper. Funding was provided by the Chinese Academy of Sciences (2011CB403206, 41071120) and 
United States Department of Agriculture, Forest Service, Northern Research Station.

\section{References}

Central Committee of the Communist Party of China and China State Council (2010) The programming outline for the protection and utilization of national forestland (2010-2020). Central Committee of the Communist Party of China and China State Council, Beijing (in Chinese)

Chang R, Fu BJ, Liu GH, Liu SG Soil carbon sequestration potential for "Grain for Green" project in Loess Plateau, China. Environmental Management. doi:10.1007/s10584-011-0087-8

Dai L, Wang Y, Su D, Zhou L, Yu D., Lewis, BJ, Qi L (in press) Major forest types and the evolution of sustainable forestry in China. Environmental Management. doi:10.1007/s00267-0119706-4

Deng Q, Zhou G, Liu S, Chu G, Zhang D Responses of soil $\mathrm{CO}_{2}$ efflux to precipitation pulses in two subtropical forests in southern China. Environmental Management. doi:10.1007/s00 267-011-9732-2

Deng H, Liu T, Liu X Forest ecosystem services and eco-compensation mechanisms in China. Environmental Management. doi: 10.1007/s00267-011-9742-0

FAO (2010) Global Forest Resources Assessment 2010. Food and Agriculture Organization United Nation, New York

Forest Stewardship Council (2011) Global FSC certificates: type and distribution. Forest Stewardship Council, Bonn

Huang Y, Zhou G, Tang X, Jiang H, Zhang D, Zhang Q Estimated soil respiration rates decreased with long-term soil microclimate changes in successional forests in southern China. Environmental Management. doi:10.1007/s00267-011-9758-5
Ji L, Wang Z, Wang X, An L Forest insect pest management and forest management in China: an overview. Environmental Management. doi:10.1007/s00267-011-9697-1

Li ZS, Liu GH, Fu BJ, Zhang JL The potential influence of seasonal climate variables on the net primary production of forests in Eastern China. Environmental Management. doi:10.1007/s00267011-9710-8

SFA (State Forestry Administration) (2009) The 7th national forest inventory. SFA, Beijing (in Chinese)

Sustainable Forest Initiative (2011) The bigger picture: conservation, integrity, community. Sustainable Forest Initiative, Washington, DC

Wu ZW, He HS, Chang Y, Liu ZH, Chen HW Development of customized fire behavior fuel models for boreal forests of Northeastern China. Environmental Management. doi:10.1007/ s00267-011-9707-3

Xie X, Wang Q, Dai L, Su D, Wang X, Qi G, Ye Y Application of China's national forest continuous inventory database. Environmental Management. doi:10.1007/s00267-011-9716-2

Yu D, Zhou L, Zhou W, Ding H, Wang Q, Wang Y, Wu X, Dai L Forest management in Northeast China: history, problems, and challenges. Environmental Management. doi:10.1007/s00267011-9633-4

Zhang PC, Shao GF, Zhao G, Le Master DC, Parker GR, Dunning JB Jr, Li QL (2000) China's forest policy for the 21st century. Science 288:2135-2136

Zhao F, Yang J, Liu Z, Dai L, He HS Balancing multiple objectives using a classification-based forest management system in Changbai Mountains, China. Environmental Management. doi: 10.1007/s00267-011-9669-5

Zhao J, Xie D, Wang D, Deng H Current status and problems in certification of sustainable forest management in China. Environmental Management. doi:10.1007/s00267-011-9620-9 